\title{
経腸用半固形剤専用注入器の有用性に関する検討
}

\author{
松原 肇*，尾鳥勝也，矢後和夫 \\ 北里大学薬学部
}

\section{Evaluation of an Injector Designed for Semi-Solid Enteral Formula}

\author{
Hajime Matsubara*, Katsuya Otori and Kazuo Yago \\ Kitasato University School of Pharmacy \\ $\left[\begin{array}{l}\text { Received April 9, } 2014 \\ \text { Accepted June 20, } 2014\end{array}\right]$
}

To evaluate the usefulness of an injector designed for semi-solid enteral formula, in comparison with a catheter tip syringe.

The subjects of this study were 20 health elderly adults and 20 medical professionals. The study was made in a crossover design for the time of the whole process for mock administration of semi-solid enteral formula and the associated survey. It contained ten questions about user-friendliness and hygiene afterwards.

The time of the whole process for the injector designed for semi-solid enteral formula is significantly shorter than that of the catheter tip syringe $(558.2 \pm 54.4$ vs $1231.5 \pm 149.6$ seconds among healthy elderly adults, and $406.6 \pm 44.6$ vs $854.8 \pm 92.1$ seconds among medical professionals). In the survey, the medical professionals group evaluated that the injector was better than the catheter tip syringe in response to all questions, except for one question, and the healthy elderly adults evaluated that the injector was better than the normal syringe in response to all questions.

The results of the study show that the injector designed for semi-solid enteral formula is more useful than the catheter tip syringe.

Key words — usefulness test, semi-solid enteral formula, an injector designed for semi-solid enteral formula, healthy elderly adult

\section{緒言}

近年，郕形を半固形に調製した経腸栄養剂を胃 瘻から短時間に投与する方法が普及しつつある. この投与方法は, 経腸栄養管理を行ううえでの副 作用である誤嶼性肺炎や下痢の予防に有用である ことが多数報告されている. ${ }^{1-3)}$ また, 経腸栄養郕 の投与にかかる時間が短いことから，患者のみな らず介護者の拘束時間も短いことが大きな利点で ある. 在宅において半固形の経腸栄養剤の使用に より, 介護者の介護に要する時間が短くなり, 介 護負担が軽減したという報告もある。 ${ }^{4)}$ 在宅医療 の継続のためには, 介護者の負担軽減は重要な要 素であり, 半固形の経腸栄養剤は, 患者のみなら
ず介護者の負担を軽減することができるため, 在 宅医療の推進にも貢献できると考えられる. 現在, 半固形の濃厚流動食は数多くの種類が販売されて いるが，医薬品経腸栄養剤で剂型が半固形である 製品は, P0201NF（販売名：ラコール ${ }^{\circledR} \mathrm{NF}$ 配合経 腸用半固形剂, イーエヌ大塚製薬(株)，岩手）の みである。よって, 在宅で半固形の経腸栄養剤を 使用する場合, 診療報酬の観点から液体の医薬品 の経腸栄養剂にカンテン末などの粘稠剤を添加し て半固形に調整することも多い.

半固形の経腸栄養剤の投与に際しては, 主に経 腸栄養用のカテーテルチップが用いられる. ${ }^{5)}$ カ テーテルチップは入手が容易であるが, 半固形の 経腸栄養剤専用の製品は存在しない. 従って, カ

\footnotetext{
* 干108-8641 東京都港区白金5-9-1
} 
テーテルチップの容量の問題から, 患者に必要な 投与量を 1 回の注入では投与することができず, カテーテルチップと胃瘻カテーテルやチューブと の接続作業を何回も繰り返す必要がある。半固形 の経腸栄養剂のカテーテルチップへの充填は, 開 放系で行われているため，接続作業が反復して行 われた場合，異物の混入や微生物污染の可能性が 高くなると考えられる。 また，半固形経腸栄養剂 は液剤より粘度が高くチューブの通過性が低いた め, 有効性が報告されている高粘度の半固形経腸 栄養剤の投与に際しては，チューブを通過させる ためにカテーテルチップを用いてある程度の力を かけて投与しなければならない。 よって，非力な 介護者の場合, 投与に難渋するということも報告 ${ }^{6}$ されている。

現在，老老介護が行われている世帯数は相当数 存在しており, ${ }^{7}$ 今後の日本の人口動態を考える と増加の一途をたどると考えられる。よって，医 療従事者のみならず，在宅で介護を行う高齢者で も安全かつ簡便に投与できる器具の開発が望まれ ている.

今回，このような問題を解決するために半固形 の経腸栄養剂を投与する専用の注入器, 経腸用半 固形剂専用注入器 (大村工業(株), 静岡) が開発 された（図 1)。この注入器は，P0201NFの容器 と直接接続することにより閉鎖系で衛生的かつ連 続的に投与することができ，更に，注入器の径が 小さく片手で投与できる設計となっているため, 汎用されているカテーテルチップより少ない力で 投与できることが特長となっている.

そこで, この注入器の臨床上の有用性を評価す るため，在宅での使用を想定した健常高齢者およ び医療従事者を対象として, 操作性試験およびア
ンケート調査を行うこととした.

\section{方法}

\section{1. 対象者}

健常高齢者 20 名掞よび医療従事者 20 名を操作 者とした。なお，健常高齢者については, 介護の 経験を有していることを本試験参加の要件とした.

\section{2. 試験方法}

試験デザインはクロスオーバー法を用いた．経 腸用半固形剂専用注入器 (注入器) を用いた投与 方法 (注入器法) と, その対照として, 現状汎用 されているカテーテルチップ (テルモ(株), 東京) を用いた投与方法（現行法）を設定した。 それぞ れの操作方法を表 1 に示す．使用する胃瘦カテー テルは,イディアルバルーンカテーテル 20 Fr.（秋 田住友ベークライト(株), 秋田) とし, 試験薬は P0201NFを用いた. P0201NFの性状を表2に示す. 投与速度は $300 \mathrm{~g}$ 当たり 6 9 分, 投与量は $300 \mathrm{~g}$ とした，健常高齢者掞よび医療従事者それぞれを 注入器法先行群又は現行法先行群に無作為に割付 け，年齢調查および握力測定を行った。その後， 操作者に対して操作方法を説明し，操作の練習を 一度実施した後, 操作を行って各作業時間を測定 した，なお，実際の投与は行わず，模擬的な状況 で操作を行った。測定項目を表 3 に示す。また, 注入器法と現行法の操作終了後, 操作者に投与準 備, 投与および片付けの簡便性に関する事項, 現 場での実施可能性, 衛生面の懸念, 方法の難易度 および継続的な使用に関する事項について，アン ケート調査を行った。 アンケートの調査項目を表 4 に示す.
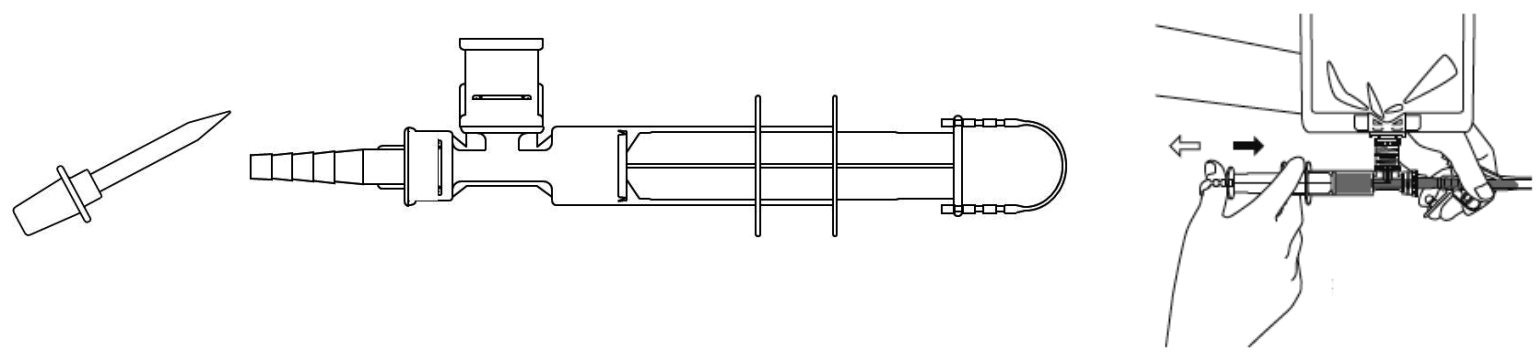

図1 経腸用半固形剤専用注入器の外見および操作方法 
表 1 注入器法および現行法の投与操作方法

\begin{tabular}{|c|c|}
\hline 注入器法 & 現行法 \\
\hline 1. 準備 & \\
\hline $\begin{array}{l}\text { (1)薬剂の容器をもむ. } \\
\text { (2)薬剂の容に宮をあける. } \\
\text { (3)薬剤の容と注入器を接続する. } \\
\text { (4)空気を抜いて, 薬剤を注入器まで押し出す. }\end{array}$ & 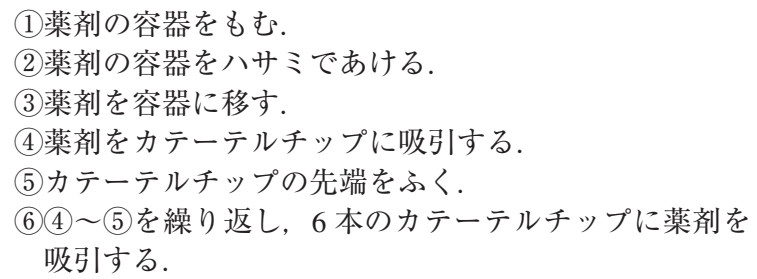 \\
\hline
\end{tabular}

2. 投与

(1)注入器と胃瘦カテーテルを接続する.

(1)カテーテルチップと胃瘦カテーテルを接続する.

(2)注入器を押し引きして, 薬剤の全てを 6〜9 分で投与 する。

(3)水の入ったカテーテルチップでフラッシングを行う.

(2)カテーテルチップから薬剤を押し出して投与する.

(3)カテーテルチップを取り換え(1)〜(2)を繰り返し, すべ てのカテーテルチップの薬剤を 6〜9分で押し出し投 与する.

(4)水の入ったカテーテルチップでフラッシングを行う.

3. 片付け

(1)使用済みの物品を廃棄する.

(1)使用済みの物品を廃棄する.

(2)薬剤を移した容器とスプーンを洗う.

表 2 P0201NF の性状

\begin{tabular}{ll}
\hline \hline 性状 & $\begin{array}{l}\text { 微褐白色のゲルで, わずかに特有の香り } \\
\text { (ミルク様 }) \text { があり, 味はわずかに甘い. }\end{array}$ \\
\hline 比重 $\mathrm{d}_{20}^{20}$ & $1.075 \sim 1.090$ \\
$\mathrm{pH}\left(20^{\circ} \mathrm{C}\right)$ & $5.8 \sim 6.3$ \\
粘度 $\left(20^{\circ} \mathrm{C}\right) *$ & $6,500 \sim 12,500 \mathrm{mPa} \cdot \mathrm{s}$ \\
\hline
\end{tabular}

* $\mathrm{B}$ 型粘度計, $12 \mathrm{rpm}$
表 3 測定項目

\begin{tabular}{ll}
\hline \hline \multicolumn{1}{c}{ 測定項目 } & \multicolumn{1}{c}{ 定義 } \\
\hline 準備時間 & 表 1の「1. 準備」に要した時間 \\
投与時間 & 表 1の「2. 投与」に要した時間 \\
片付け時間 & 表 1の「3. 片付け」に要した時間 \\
総投与時間 & 準備時間, 投与時間および片付け時間の \\
& 合計時間 \\
\hline
\end{tabular}

表 4 アンケート調査項目（回答は注入器法又は現行法の二者択一式）

Q1）投与器具（注入器又はシリンジ）に薬剤を吸い入れることが簡単なのは, どちらでしたか？

Q2）全体的に準備が簡単なのは，どちらでしたか？

Q3）投与器具（注入器又はシリンジ）と胃ろうカテーテルとの接続が簡単なのは，どちらでしたか？

Q4）薬剤の押し出しが, 軽い力でできたのはどちらでしたか?

Q5）全体的に投与が簡単なのは，どちらでしたか?

Q6）全体的に片付けが, 簡単なのはどちらでしたか?

Q7）狭いスペース（ベッドサイドなど）でもできるのは，どちらですか?

Q8）細菌やゴミ・ホコリなどの混入が気にならないのは, どちらですか?

Q9）説明を聞いて，すぐにできたのはどちらですか?

Q10）1日3回（朝・昼・晚）, 毎日実施できそうなのは, どちらですか?

結果については, 準備時間, 投与時間, 片付け 時間および総投与時間の記述統計量を算出し, 対 応のある $t$ 検定を行った（有意水準 0.05 , 両側). アンケート調査については, 集計を行い, 割合を 算出した，統計解析には, SAS for Windows Release 9.2 （SAS Institute Inc, Cary, NC, USA）を用いた。

\section{結果}

\section{1. 対象の背景}

操作者の背景を表 5 に示す．健常高齢者の性別 は男性 9 名, 女性 11 名, 医療従事者の性別は 20 名すべて女性であった．健常高齢者の年齢は 74.2 
表 5 操作者背景の要約

\begin{tabular}{|c|c|c|c|c|}
\hline \multicolumn{3}{|c|}{ 項目 } & $\begin{array}{c}\begin{array}{c}\text { 健常高齢者 } \\
(\mathrm{n}=20)\end{array}\end{array}$ & $\begin{array}{c}\text { 医療従事者 } \\
(\mathrm{n}=20)\end{array}$ \\
\hline \multirow{2}{*}{ 性別 } & 男性 & 例数 & 9 & 0 \\
\hline & 女性 & 例数 & 11 & 20 \\
\hline \multirow[t]{2}{*}{ 年齢（歳） } & & 平均 \pm 標準偏差 & $74.2 \pm 3.0$ & $40.0 \pm 7.9$ \\
\hline & 全体 & 平均 \pm 標準偏差 & $29.89 \pm 8.08$ & $27.73 \pm 3.93$ \\
\hline \multirow[t]{2}{*}{ 握力（kg） } & 男性 & 平均 \pm 標準偏差 & $37.23 \pm 5.69$ & - \\
\hline & 女性 & 平均 \pm 標準偏差 & $23.88 \pm 3.16$ & - \\
\hline
\end{tabular}

$\mathrm{n}$ : 評価対象例数, - : 集計未実施.

表 6 投与操作時間の要約

\begin{tabular}{llccc}
\hline \hline & & $\begin{array}{c}\text { 注入器法 } \\
\text { 平均 } \pm \text { 標準偏差 }\end{array}$ & $\begin{array}{c}\text { 従来法 } \\
\text { 平均 } \pm \text { 標準偏差 }\end{array}$ & \multirow{2}{*}{$P^{*}$} \\
\hline \multirow{2}{*}{ 健常高齢者 } & 準備時間 (秒) & $85.6 \pm 19.6$ & $775.7 \pm 134.4$ & $<0.0001$ \\
$(\mathrm{n}=20)$ & 投与時間 (秒) & $446.3 \pm 42.9$ & $390.3 \pm 22.9$ & $<0.0001$ \\
& 片付け時間 (秒) & $26.4 \pm 7.7$ & $65.6 \pm 13.4$ & $<0.0001$ \\
& 総投与時間 (秒) & $558.2 \pm 54.4$ & $1231.5 \pm 149.6$ & $<0.0001$ \\
\hline \multirow{2}{*}{ 医療従事者 } & 準備時間 (秒) & $60.0 \pm 17.1$ & $401.6 \pm 83.6$ & $<0.0001$ \\
$(\mathrm{n}=20)$ & 投与時間 (秒) & $326.9 \pm 36.3$ & $387.9 \pm 11.8$ & $<0.0001$ \\
& 片付け時間 (秒) & $19.8 \pm 5.9$ & $65.3 \pm 13.3$ & $<0.0001$ \\
& 総投与時間 (秒) & $406.6 \pm 44.6$ & $854.8 \pm 92.1$ & $<0.0001$ \\
\hline
\end{tabular}

$\mathrm{n}$ : 評価対象例数, *対応のある $t$ 検定.

\pm 3.0 歳 (平均土標準偏差), 握力は $29.89 \pm 8.08$ $\mathrm{kg}$ であった．健常高齢者の性別で層別した握力 は，男性 $37.23 \pm 5.69 \mathrm{~kg}$ ，女性 $23.88 \pm 3.16 \mathrm{~kg}$ であった。医療従事者の年齢は $40.0 \pm 7.9$ 歳，握 力は $27.73 \pm 3.93 \mathrm{~kg}$ であった。健常高齢者と医 療従事者の握力は，文部科学省が実施している一 般の 70 歳代および 40 歳代の握力の調査結果 (http://www.e-stat.go.jp/SG1/estat/List.do?bid $=000001030954 \&$ cycode $=0,2014$ 年 2 月 17 日）と 比較して大きな差は認められなかった.

\section{2. 投与作業に要する時間の検討}

投与操作時間の結果を表 6 に示す。健常高齢 者および医療従事者のいずれも，全員 1 回の説明 および練習で投与操作を実施することができた.

\section{（1）健常高齢者}

準備時間は, 注入器法 $85.6 \pm 19.6$ 秒, 現行法 $775.7 \pm 134.4$ 秒であった。片付け時間は，注入 器法 $26.4 \pm 7.7$ 秒, 現行法 $65.6 \pm 13.4$ 秒であった. 総投与時間は, 注入器法 $558.2 \pm 54.4$ 秒, 現行法
$1231.5 \pm 149.6$ 秒であった。準備時間, 投与時間, 片付け時間および総投与時間に群間で有意差が認 められた。

\section{（2）医療従事者}

準備時間は, 注入器法 $60.0 \pm 17.1$ 秒, 現行法 $401.6 \pm 83.6$ 秒であった. 片付け時間は, 注入器法 $19.8 \pm 5.9$ 秒, 現行法 $65.3 \pm 13.3$ 秒であった. 総投 与時間は, 注入器法 $406.6 \pm 44.6$ 秒, 現行法 854.8 \pm 92.1 秒であった，準備時間, 投与時間, 片付け時 間および総投与時間に群間で有意差が認められた。

\section{3. アンケート調査}

\section{（1）健常高齢者}

アンケート調査の結果を図 2 に示す。健常高齢 者では準備に関する事項（Q1 および Q2）では 90\%, 投与に関する事項（Q3～5）では 85\%以上, 片付けの簡便性に関する事項（Q6）では 100\%, 現場での実施可能性, 衛生面の懸念, 方法の難易 度，継続的な使用に関する事項（Q7～10）では 90\%以上が注入器法を選択していた。 
Q1) 投与器具 (注入器又はシリンジ)に薬剂を吸い 入れることが簡単なのは, どちらでしたか?

Q2) 全体的に準備が簡単なのは, どちらでしたか?

Q3) 投与器具 (注入器又はシリンジ) と胃ろうカテー テルとの接続が簡単なのは, どちらでしたか?

Q4)薬剤の押し出しが, 軽い力でできたのはどちら でしたか?

Q5) 全体的に投与が簡単なのは, どちらでしたか?

Q6)全体的に片付けが, 簡単なのはどちらでしたか?

Q7)狭いスペース(ベッドサイドなど) でもできるの は, どちらですか?

Q8) 細菌やゴミ・ホコリなどの混入が気にならないの は, どちらですか?

Q9)説明を聞いて, すぐにできたのはどちらですか?

Q10)1 日 3 回(朝・昼・晚)，毎日実施できそうなの は, どちらですか?

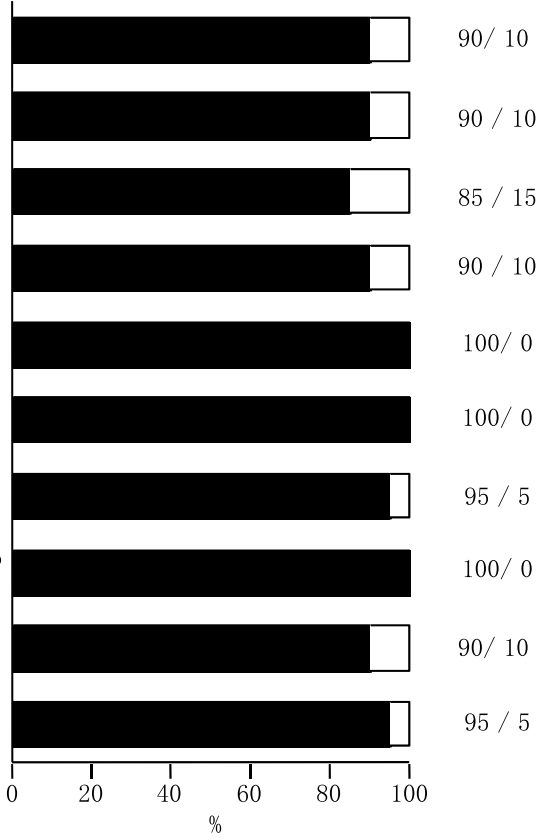

図 2 アンケート調査結果（健常高齢者）

$\square$ 注入器法, $\square$ 現行法. $(\mathrm{n}=20)$

Q1) 投与器具 (注入器又はシリンジ)に薬剤を吸い 入れることが簡単なのは,どちらでんたか?

Q2)全体的に準備が簡単なのは, どちらでしたか？

Q3) 投与器具 (注入器又はシリンジ)と胃ろうカテー テルとの接続が簡単なのは, どちらでしたか?

Q4)薬剤の押し出しが, 軽い力でできたのはどちら でしたか?

Q5) 全体的に投与が簡単なのは, どちらでしたか?

Q6)全体的に片付けが, 簡単なのはどちらでしたか?

Q7)狭いスペース(ベッドサイドなど) でもできるの は,どちらですか?

Q8) 細菌やゴミ・ホコリなどの混入が気にならないの は,どちらですか?

Q9)説明を聞いて, すぐにできたのはどちらですか?

Q10)1 日 3 回(朝・昼·晚), 毎日実施できそうなの は,どちらですか?

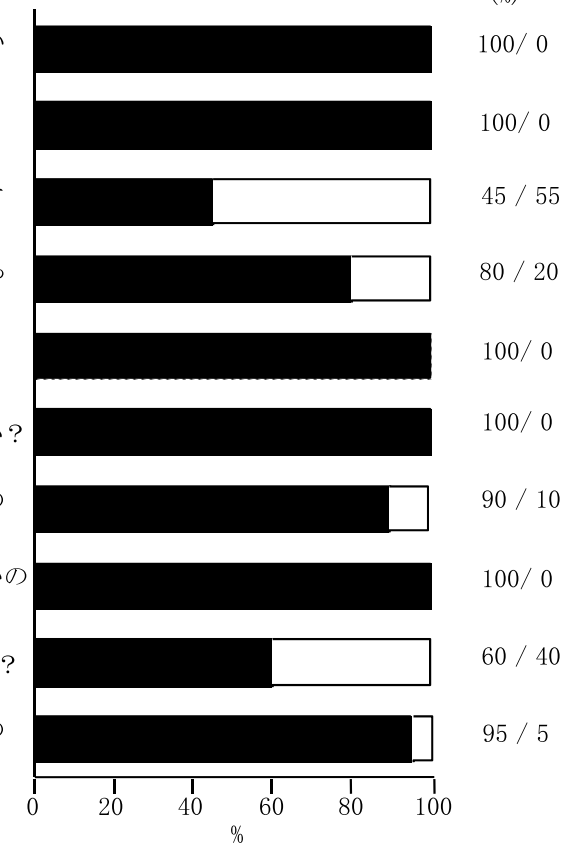

図 3 アンケート調査結果（医療従事者）

口注入器法, $\square$ 現行法. $(\mathrm{n}=20)$

\section{（2）医療従事者}

アンケート調査の結果を図 3 に示す。医療従事 者では準備に関する事項（Q1 および Q2）では $100 \%$ ，投与に関する事項（Q3～5）では Q3 の $45 \%$ 以外は $80 \%$ 以上，片付けの簡便性に関する
入器法/現行法

(\%)

/ 10

/ 10

$00 / 0$

$00 / 0$

$5 / 5$

$00 / 0$

10

$5 / 5$

注入器法/現行法

(\%)

$100 / 0$

$100 /$

55

/ 20

/ 0

$0 / 0$

10

/ 0

40

/ 5 以上が注入器法を選択していた。

事項（Q6）では $100 \%$ ，現場での実施可能性， 衛生面の懸念, 方法の難易度, 継続的な使用に関 する事項（Q7〜10）では Q9 の 60\% 以外は $90 \%$ 


\section{考察}

注入器法の投与操作にかかる総投与時間は, 健 常高齢者および医療従事者とも現行法と比べて, 半分以下に短縮された. 今回開発された注入器は, 経腸栄養剤の容器と直接接続することができ，ま た，投与終了後は容器とともに廃亲できるため, 時間短縮の要因に繋がったと考えられる．投与操 作にかかる時間の短縮は，医療機関で使用する場 合，医療従事者の業務の効率化が可能であり，ま た，在宅で使用する場合は介護者の負担の軽減に 貢献できると考えられる.

現行法は投与に際して経腸栄養剤の容器への移 し替えや，カテーテルチップでの吸引が必要にな るため, 経腸栄養剤が外気に接触する時間が長い. 一方，注入器を使うことにより，製剤容器と注入 器を接続するだけで連続的な投与が可能になり, 構造的にも外気に接する部分が少なく, 衛生的な 投与が可能であり，使用した用具を洗浄する必要 もない，従って，用具の不十分な洗浄による污染 等の発生も回避可能であると考えられる。アン ケート調査においても, 衛生面の懸念に関する質 問（Q8）においては, 健常高齢者および医療従 事者とも全員が注入器法のほうが気にならないと 回答している。在宅では，医療機関と同様の衛生 管理を行うことは難しく，在宅での衛生管理に不 安がある医療従事者は $36 \%$ であると報告 ${ }^{5}$ も あり, 注入器法は衛生面においても優れていると 考えられた。

アンケート調査においては, 健常高齢者の場合, 全ての設問において $85 \%$ 以上の割合で注入器を 使用したほうがよいとの結果であり，医療従事者 の場合も，Q3 および Q9 以外は，80\%以上の割 合で注入器を使用したほうがよいとの結果であっ た。

医療従事者の Q3 および Q9 の回答が，ほかの 設問に比べ，注入器法の選択率が低かったのは医 療従事者がカテーテルチップの操作に慣れがある ためと考えられた。これらの質問は，健常高齢者 においては，85\%以上の割合で注入器法のほうが 優れていると回答しており，在宅で高齢者が介護 で使用することを考慮した場合には，有用な注入
器であると考えられる.

投与に関する事項については, 現行法と比べて 注入器法の方が経腸栄養剂の押し出しに必要な力 が少なく，狭いスペースでも実施でき簡便である との回答が多かった。 また, 注入器法は新しい投 与システムであるが, 健常高齢者および医療従事 者のいずれも操作方法を 1 回の説明および練習で 理解でき, 操作が可能であった. さらに, 注入器 法は健常高齢者と医療従事者との間で，準備時間 および片付け時間に大きな差がないことから, 職 種・年齢を問わず簡便な操作が可能であると考え られた。

経腸栄養剤は長期間にわたって投与されること も多く, 注入器法は現行法と比べて作業時間, 作 業内容が少なく, 薬剤の押し出しにあまり力を必 要としないため, アンケートでも継続しやすいと の回答が多かった。従って, 在宅での経腸栄養管 理を高齢の介護者が行う場合でも, 経腸栄養管理 の継続的な実施が可能であると考えられた. 以上 より，P0201NFと新たに開発された注入器を用 いた投与方法は，投与にかかる時間およびアン ケート調査の結果, 現行の投与方法と比べて, 有 用性に優れていると考えられた。

本試験の限界について記載する。半固形経腸栄 養剤投与時の操作性に関しては，使用する製剤の 粘度などの性状並びに使用する胃瘻カテーテルの 長さおよび Fr. サイズなどが影響を与えることが 報告されている。 ${ }^{8)}$ 従って, 本試験で得られた結 果は, 本試験で設定した条件に限定される. 今後, 使用する製剂や胃瘻カテーテルにかかわらず投与 を容易にする器具の開発が望まれる.

\section{利益相反}

本試験は，イーエヌ大塚製薬(株)より委託を受 けて実施した。著者らはその他の開示すべき利益 相反はない

\section{引用文献}

1）合田文則, “胃瘻からの半固形短時間摂取法ガイ ドブックー胃瘻患者のQOL 向上をめざして - , 
医歯薬出版, 東京, 2006, pp9-18.

2) Kanie J, Suzuki Y, Akatsu H, Kuzuya M, Iguchi A, Prevention of Late Complications by Half-Solid Enteral Nutrients in Percutaneous Endoscopic Gastrostomy Tube Feeding, Gerontology, 2004, 50, 417 419.

3) Nishiwaki S, Araki H, Shirakami Y, Kawaguchi J, Kawade N, Iwashita M, Tagami A, Hatakeyama H, Hayashi T, Maeda T, Saitoh K, Inhibition of gastroesophageal reflux by semi-solid nutrients in patients with percutaneous endoscopic gastrostomy, JPEN $J$ Parenter Enteral Nutr, 2009, 33, 513-519.

4）岡田晋吾, 小川滋彦, 半固形化経腸栄養剤の投与 が介護負担に及ぼす影響, 静脈経腸栄養, 2011,
26, 1399-1406.

5） NPO法人PEGドクターズネットワーク，日本栄 養材形状機能研究会, 胃瘻に関する全国調査第 5 回「在宅胃瘦患者における半固形化経腸栄養 剂の使用状況調査」アンケート結果, 2012.

6）吉田貞夫, 半固形化栄養法のQ\&A, 月刊ナーシ ング, 2007, 348, 42-53.

7）内閣府編, “平成25年版 高齢社会白書”, 印刷通 販, 東京, 2013,pp23-28.

8）高橋勇一, 柳沼信久, 五百川和明, 薮内昭久, 半固 形化栄養剤投与の視点から考える胃㾇カテーテ ルの選択, 在宅医療と内視鏡治療, 2008, 12(1), 31-36. 